Communist Politics 


\title{
Communist Politics
}

\section{A Reader}

\author{
Edited by \\ Stephen White \\ University of Glasgow
}

and

Daniel Nelson

University of Kentucky

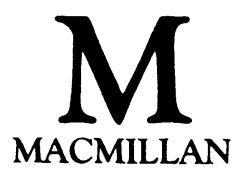


() Stephen White and Daniel Nelson 1986

All rights reserved. No reproduction, copy or transmission of this publication may be made without written permission.

No paragraph of this publication may be reproduced, copied or transmitted save with written permission or in accordance with the provisions of the Copyright Act 1956 (as amended).

Any person who does any unauthorised act in relation to this publication may be liable to criminal prosecution and civil claims for damages.

First published 1986

Published by

MACMILLAN EDUCATION LTD

Houndmills, Basingstoke, Hampshire RG21 2XS

and London

Companies and representatives

throughout the world

British Library Cataloguing in Publication Data

Communist politics: a reader.

$\begin{array}{lll}\text { 1. Comparative government } 2 \text {. Communist } & \end{array}$

countries-Politics and government

I. White, Stephen, 1945- II. Nelson, Daniel N.

$320.3^{\prime} 09171^{\prime} 7 \quad$ JC474

ISBN 978-0-333-41407-1

DOI 10.1007/978-1-349-18339-5

ISBN 978-1-349-18339-5 (eBook) 


\section{Contents}

Preface

Introduction: The Comparative Study of Communist Politics

\section{PART I HISTORICAL ORIGINS}

1 The Communist Movement: from Monolith to Polymorph

Michael Waller and Bogdan Szajkowski

\section{PART II STRUCTURES OF GOVERNMENT}

2 Elections in Communist Party States Alex Pravda

3 The Supreme Soviet and Budgetary Politics in the USSR Stephen White

4 The Institutional Development of a Minimal Parliament: the Case of the Polish Sejm

David M. Olson and Maurice D. Simon

5 Yugoslavia: Towards Self-Management?

Ralph Pervan

6 State Reforms in the People's Republic of China since 1976:

a Historical Perspective

David S. G. Goodman

\section{PART III THE RULING PARTIES}

7 The Soviet Communist Party: Trends and Problems John H. Miller

8 The Polish Party in Crisis, 1980-82

David S. Mason

9 The Communist Party of Cuba since the First Congress William M. LeoGrande

10 Party-building since Mao: a Question of Style? 
PART IV GROUPS AND THE POLICY PROCESS

11 Interest Groups and Communist Politics Revisited

H. Gordon Skilling

12 The Impact of the Military on Soviet Society

Timothy J. Colton

13 Inequalities and the Politicization of the Polish Working Class Jack Bielasiak

14 Worker-Party Conflict in Romania

Daniel N. Nelson

15 Economic Policy-Making in China

Michel Oksenberg

\section{PART V POLICY OUTCOMES AND COMPARATIVE PERSPECTIVES}

16 From Soviet Studies to Comparative Politics: the Unfinished Revolution

Valerie Bunce and John M. Echols III

17 Human Rights under State Socialism

David Lane

18 Worker Welfare Systems in Marxist-Leninist States: a Comparative Perspective

Alexander J. Groth

19 Does Socialism Mean Greater Equality? A Comparison of East and West along Several Major Dimensions

John M. Echols III

Bibliography

Index 


\section{List of Contributors}

Jack Bielasiak, Indiana University

Valerie Bunce, Northwestern University

Timothy J. Colton, University of Toronto

†John M. Echols III, University of Illinois

David S. G. Goodman, University of Newcastle-upon-Tyne

Alexander J. Groth, University of California at Davis

William M. LeoGrande, American University, Washington DC

David Lane, University of Birmingham

David S. Mason, Butler University

John H. Miller, LaTrobe University

Daniel N. Nelson, University of Kentucky

Michel Oksenberg, University of Michigan

David M. Olson, University of North Carolina, Greensboro

$\dagger$ Ralph Pervan, University of Western Australia

Alex Pravda, University of Reading

Tony Saich, Sinologisch Instituut, University of Leiden

Maurice D. Simon, University of North Carolina, Greensboro

H. Gordon Skilling, University of Toronto

Bogdan Szajkowski, University College, Cardiff

Michael Waller, University of Manchester

Stephen White, University of Glasgow 


\section{Preface}

Comparative communist politics is one of the most rapidly expanding sub-fields of political science. There are at least three reasons, in the mid and late 1980s, why this should be the case. The first concerns the considerable expansion in the number of communist or Marxist-Leninist regimes that has taken place over the past twenty years, or even over the past decade. At the end of the 1950s there were just fourteen generally recognised communist systems, in the USSR, Eastern Europe and Asia. By the early 1960s the Cuban revolution had publicly associated itself with Marxism-Leninism, the first regime in Latin America to do so; and by the mid-1970s communist governments had become established throughout most of South-East Asia, in Kampuchea, Laos and South Vietnam. At the same time a number of radical revolutionary movements, many of them of Marxist-Leninist inspiration and affiliation, came to power in various parts of Africa, Asia and Latin America. There has been some debate about the extent to which such regimes, many of them military, Islamic and of doubtful durability, may be classified as 'communist systems', and in this book we limit ourselves almost exclusively to the 'established' communist regimes - those that publicly identify with Marxism-Leninism, share important political and economic characteristics and are generally recognised as such. The expansion in the number of systems, at both the local and national level, claiming some sort of relationship to Marxism-Leninism is nevertheless a global reality of the 1980 s, and it has given a continuous stimulus to the sub-discipline - comparative communism - which seeks to make sense of such developments academically.

A second reason for the expansion of comparative communist politics is the greater wealth of information and data that are now available for the serious student of the subject. Communist regimes have traditionally been among the world's most secretive systems, maintaining a firm and effective domestic censorship and limiting the flow of information both within each country and across its borders. There are obvious advantages in any such arrangement for regimes which are seeking to maintain their power other than through competitive elections and which are also attempting to socialise their populations into new, collectivist norms. At the same time 
the tight control of information leads to practical difficulties for planners, for party officials and for social scientists, who are expected in these countries to make a positive contribution to the formation of party and state policy; and with the slowdown in economic growth that the communist countries have generally experienced since the 1960s, a lack of information or openness in decision-making also runs the risk of encouraging alienation or even active opposition among the populations by whom any resulting sacrifices must be borne. The 1970s and 1980s have accordingly seen substantial improvements in access to information in most communist countries: in the USSR, for instance, reports of weekly Politburo meetings have been appearing in the press since the end of 1982, and in China a national statistical handbook has been appearing since 1981, together with a profusion of data of all kinds. Even for foreigners access to archives, to government officials, to villages for field studies, or even (in a few cases) to the mass public have all improved greatly, with major consequences for the academic literature on communist politics.

Thirdly, and no less important, the years up to the 1980s have seen important developments in theoretical approaches to the politics of the communist countries. The totalitarian paradigm, which was still dominant in the 1950 s, came under increasingly critical scrutiny as the 1960 s advanced. In turn a variety of other approaches, from 'modernisation' and 'convergence' to 'bureaucratic politics' and 'corporatism', made their appearance. By the 1980 s it was probably fair to say that no alternative orthodoxy had become dominant; rather, a plurality of approaches had become accepted as legitimate or even desirable in relation to a group of political systems which were increasingly recognised to vary from each other and to contain a level of contradiction and complexity which made any single all-embracing formula more of an obstacle than an aid to understanding. Perhaps in consequence, scholarly interest has turned increasingly from 'macro' propositions in relation to communist systems as a whole towards 'micro' studies of more limited questions. Topics such as the role of groups, coalition formation, ethnic nationalism, the nature of associational bodies such as trade unions, the role of the mass media, political recruitment, the work of legislative bodies and regime-citizen relations, and the policy process in particular areas have all attracted a greater degree of attention and have begun to be dealt with in a manner which reflects both a greater concern for developments elsewhere in comparative politics and the improvements that have taken place in terms of access to information over the intervening years. By the late 1980s the study of comparative communist politics had attained, if not a higher level of development, then at least a greater maturity and theoretical awareness, combined with an expanding body of solidly documented individual and more general case studies.

In the chapters that follow we have sought to reflect some of the best of 
this recent work under five broad headings. The first section, which is limited to a single article, deals in a wide-ranging way with the historical origins of contemporary communism and with its contemporary global presence. The second, on structures of government, examines the formal framework of state politics in the communist countries with particular reference to the role of elections and of legislative bodies. In the third section we turn to the ruling communist parties, which direct this state machinery and which dominate political life in their respective countries; and in the fourth section we consider the variety of pressures, of both an institutional and an informal kind, which influence the parties and through them the pattern of public policy in these countries. Finally, in the fifth section, we consider a number of comparative perspectives upon the politics of the communist-ruled nations, including authors who reach rather different conclusions upon these hotly contested questions. Each of these later sections contains four or five different chapters, the first of which is normally a general or scene-setting paper, followed by others which deal in more detail with the same question in a particular national context. In each case we have sought, so far as possible, to include work published in the 1980s and reflecting current approaches to comparative communist politics. We have also included the work of political scientists who are based on both sides of the Atlantic, and in two cases further afield, in a manner which we hope provides an international as well as a contemporary perspective upon the work that is currently being conducted on the comparative politics of communist systems.

Even in a large book such as this there has been severe pressure upon space, and we have had to leave out many papers that under ideal conditions we would certainly have wished to include. We have, however, been able to find room for 19 separate contributions by some twenty-one different authors, and our selection is we hope a fair representation of some of the best of the work that has recently been appearing in communist politics. Most of the articles that have been included are reprinted at their original length; a few, however, have been shortened slightly, in most cases by the reduction of notes rather than of the text itself. All the articles have also been converted to a name-date style of referencing; a full list of sources, together with some other recent work on communist politics, appears in the bibliography at the end of the book. The transliteration of Russian is based throughout upon the style employed by the journal Soviet Studies, and Chinese transliteration is based upon the currently favoured pinyin system. In other respects the stylistic conventions of each article have been respected. Almost every article, however, has been partly rewritten and updated for this book, at least in terms of references to subsequent literature; a number of minor errors and misprints have been corrected; and in general, the versions which appear in this collection reflect so far as possible the state of knowledge in their respective subjects 
as of the mid-1980s. The present texts have in each case been approved by the authors concerned, and appear by permission of author and publisher. The appropriate acknowledgement appears on the first page of each chapter.

In conclusion, we would like to thank the authors of the chapters included in this volume, not simply for their permission to republish, but also for their active assistance with the revised text. Thanks are also due to Steven Kennedy, the publishing editor, for his interest in this project and for his detailed advice at all stages of its preparation. Drafts of edited chapters for this volume were typed by Kim Hayden at the University of Kentucky, and other sections by Elspeth Shaw, Avril Johnstone and Barbara Fisher at the University of Glasgow. Kathie Golden, a PhD student at the University of Kentucky, assisted in the preparation of references for many of the chapters. Therese $\mathrm{C}$. Nelson assisted in proofing much of the text. Their help is appreciated greatly; none of them, of course, bears any responsibility for remaining errors or infelicities. The project as a whole was jointly planned by the two editors, first of all in a walk around Glasgow's Botanic Gardens and later in correspondence, and each was responsible for arranging for the preparation of about half of the edited chapters. The general introduction which follows was written by Daniel Nelson, and this preface and the section introductions by Stephen White; both authors, however, accept full responsibility for all aspects of the volume as a whole, which reflects the need they have felt for some time as teachers of comparative communist politics for an up-to-date and reasonably comprehensive selection of recent papers which could helpfully be recommended to their students. We hope that students and scholars in other universities, and in comparative politics as well as communist studies, will also find it of value.

Stephen White

Daniel Nelson 